\title{
CATALAN TERMINOLOGICAL DATABASES AS A MEANS OF LANGUAGE POLICY
}

\author{
ESZTER SERMANN
}

University of Szeged

\begin{abstract}
Terminological databases are reliable and useful tools for translators, because they contain not only the basic grammatical information related to the terms, but also facilitate the conceptual analysis necessary for the translation of the terms. High quality databases that are compiled according to terminological principles also serve language policy purposes and fulfil terminological policy tasks. In recent years, the Catalan language as an element of Catalan identity has also become the focus of interest in parallel with the independence movement in Catalonia. This paper aims to present and analyse five Catalan terminological databases compiled by TERMCAT, the Catalan Center for Terminology and two universities in Catalonia. A comprehensive classification and evaluation system will be used for the analysis of the databases, which includes four main aspects: background information, technical parameters, information on the content and the usage of the termbases. The databases presented here are the result of a conscious effort by the professionals responsible for terminology and the database as well as the associated workflow, can serve as a good practice for other language communities.
\end{abstract}

Keywords: Terminological Databases, Catalan Language Policy, Terminological Principles, Classification and Evaluation System, Technical Parameters.

Resumen: Las bases de datos terminológicas son herramientas fiables y útiles para los traductores, ya que no solo contienen las informaciones gramaticales básicas relacionadas con los términos, sino que también facilitan el análisis conceptual necesario para la traducción de los mismos. Las bases de datos de alta calidad compiladas según los principios terminológicos también sirven a los fines de la política lingüística y cumplen tareas de política terminológica. En los últimos años, la lengua catalana como elemento de la identidad catalana también se ha convertido en el centro de interés en paralelo al movimiento independentista en Cataluña. Este trabajo pretende presentar y analizar cinco bases de datos terminológicas catalanas realizadas por TERMCAT, el Centro Catalán de Terminología y dos universidades en Cataluña. Para el análisis de las bases de datos se utilizará un sistema complejo de clasificación y evaluación que incluye cuatro aspectos principales: información de fondo, parámetros técnicos, información sobre el contenido y el uso de las bases de datos terminológicas. Las bases de datos aquí presentadas son el resultado de un esfuerzo consciente por parte de los profesionales responsables de la terminología y de las bases de datos, así como del flujo de trabajo asociado, pueden servir como una buena práctica para otras comunidades lingüísticas.

Palabras clave: bases de datos terminológicas, política lingüística catalana, principios terminológicos, sistema de calificación y evaluación, parámetros técnicos. 
Catalan Terminological Databases as a Means of Language Policy

\section{Introduction}

In recent years, the Catalan language as an element of Catalan identity has become the focus of interest in parallel with the independence movement in Catalonia. After the Franco era (1936-1975), when Catalan was given co-official status (1979) in some autonomous communities, after many years of silence the language was rediscovered, and efforts to standardise terminology were launched in an organized way. Scientific and technical progress required language development and terminology planning, which meant that terminological work was launched under central, autonomous provincial control (see Cabré Castellví, 1996, 1999). This paper aims to present and analyse five Catalan terminological databases compiled by TERMCAT, the Catalan Center for Terminology and two universities in Catalonia. A comprehensive classification and evaluation system will be used for the analysis of the databases, which includes four main aspects: background information, technical parameters, information on the content and the usage of the termbases.

\section{Terminological databases and language policy}

A terminological database is a collection of electronically stored terminology data, created from an onomasiological approach, based on mapping the conceptual system of the subject field. It contains terms and their definitions of one or several subject fields in one or more languages (Sermann - Tamás, 2010: 113). Terminological databases are not only efficient translation tools, but they also can fulfil language policy related goals since the edition and publication of well-elaborated databases contribute to express linguistic and terminological identities.

In everyday practice, terminological databases are often similar to online dictionaries in many aspects, however, in the level of editing principles, there are fundamental differences between the two genres (see Fóris, 2002; Sermann - Tamás, 2013). The specialized language lexicographer's approach is semasiological (sign-oriented), while the terminologist's starting point is the concept (Brekke, 2001). Due to their different working methods, their products will be different as well: specialized language lexicographers start from the terms, they compile dictionaries with words in alphabetical order especially for specialized translators, while the terminographer, after outlining the conceptual system of a certain domain, compiles databases not only for translators, but for professionals, experts and document editors as well. At the level of theoretical principles, the two genres can be distinguished very clearly, but in practice it has been demonstrated that a borderline cannot always be drawn, there are hybrid versions as well (Sermann - Tamás, 2010). Various authors agree that, during the translation process, translators often act as terminologists as well (Fischer, 2015; Tamás, 2015), and with terminological databases compiled according to the concept-based approach, their work becomes easier and more effective.

76 | Acta Hispanica, Hungría, Supplementum III: 75-87, 2021, ISSN 1416-7263, e-ISSN 2676-9719 


\section{Eszter Sermann}

Databases created according to terminological principles also play an important role in the life of the community from the point of view of language policy and terminology policy. The UNESCO Guidelines for Terminology Policies describes terminology policy as a set of written strategies that aim to coordinate terminology use of various groups of society (UNESCO, 2019). One of the tasks set out in the document is to examine the best way to publish data on terminology development. Papp (2019) surveys international terminology organizations that offer guidance in designing a national terminology policy and in establishing a national term bank. When they outlined the tasks of Hungarian terminology strategy, Fóris and Bölcskei (2019) stated that a terminology database, which is the result of cooperation between experts and terminologists, is an essential tool for knowledge management and an effective knowledge repository.

\section{Analysis of Catalan terminological databases}

In recent years, several changes took place in the status and official use of Catalan and Spanish in Catalonia, and the practical aspects of linguistic autonomy have been reinterpreted several times in parallel with the issue of Catalan independence (see Pujol Berché 2013; Nemes, 2015; Déri - Faluba, 2018; Lénárt, 2018; Németh, 2018; Sermann 2020, 2021). Language is an important part of Catalan identity, and today the intentions of proponents of independence or unity are also reflected in their language use, as those who argue for independence do so in Catalan and those who argue for unity speak in Spanish (see Szente-Varga, 2012; Berta, 2018).

In this section, a comprehensive, multi-criteria system is used to analyse five terminological resources in Catalan (Tamás - Sermann, 2019, 2020): 1) Cercaterm and Neoloteca, two databases of TERMCAT; 2) UBTERM database, University of Barcelona; 3) UPCTERM, Linguistic and Technological Services of the Polytechnic University of Catalonia; 4) Catalan terminology for IATE, TERMCAT. This evaluation system was developed based on criteria for the analysis of print and online dictionaries (Fóris - Rihmer, 2007; Gaál, 2012), and it is structured around the following criteria: 1) background information on the database (overview of databases available in the domain, classification by trend, information on the database owner, the target group and purpose of use); 2) technical parameters (nature of the software, database accessibility); 3) content information (general characteristics of the database, detailed characteristics of its structure); 4) information on the use of the database (ease of use, data updating and reliability, database innovation, social utility and professional relevance). 
Catalan Terminological Databases as a Means of Language Policy

\subsection{Cercaterm and Neoloteca}

The Cercaterm and Neoloteca databases were created by the Catalan terminology center, TERMCAT (https://www.termcat.cat/ca). The website of TERMCAT is available in Spanish, Catalan and English, and its objective is to promote the standardization process of the Catalan language, respecting multilingualism and diversity. The organization is run by the Board of Directors (Consell de Direcció), and terminology standardization (i.e. the selection of preferred terms from among the term candidates necessary to disseminate new knowledge in the various subject areas) is carried out by the Board of Supervisors (Consell Supervisor). Termcat collaborates with Spanish and international organizations committed to terminology, promotes multilingual terminology work with a view to promoting Catalan in the international arena, works closely with universities in the Catalan speaking area, liaises with professionals involved in terminology projects, and contributes to university training by providing traineeship opportunities for undergraduate and postgraduate students in terminology, humanities, translation and interpreting. Cercaterm and Neoloteca serve both a language policy purpose and a standardization role. The databases produced by TERMCAT widely disseminate standardised terms, thus serving as a primary reference for clarifying concepts and for the use of terms.

Both databases are intended primarily as useful tools for translators, interpreters and documentation producers. The question of whether Cercaterm is a prescriptive or descriptive database is answered in the Cercaterm Help menu item, in the description of resources and working methods. Descriptive databases (see Tamás - Sermann, 2019, 2020 for more details) provide users with information on terminological data, whereas prescriptive databases are normative. Cercaterm has both features: on the one hand, it contains concepts and terms standardised by the Board of Supervisors, in which case the prescriptive character becomes more dominant; and on the other hand, it collects the results of terminological research carried out by TERMCAT, and can therefore be considered a descriptive database. In the case of Neoloteca, it can be considered a prescriptive database, although the use of terms is not mandatory, but a recommendation.

As for technical parameters, the documentation on Cercaterm's and Neoloteca's user interfaces does not make it clear what software was used to create them, but it does say that the institution makes its terminology corpus available to researchers and doctoral students, and that the Ges'Term terminology management software can be downloaded free of charge from its website, which allows the main tasks related to terminology work to be carried out: creating terminographic entries and recording information related to them. Both databases are open to the public and accessible to anyone without registration, as they aim to disseminate the terminological data standardised by the institution as widely as possible. Users can register on the site, which serves as a user interface for the databases, and once registered, they can contact

78 | Acta Hispanica, Hungría, Supplementum III: 75-87, 2021, ISSN 1416-7263, e-ISSN 2676-9719 


\section{Eszter Sermann}

Termcat's customer service, make suggestions and send comments. There is no dedicated mobile phone application developed for the databases, but their interfaces are optimised for mobile phones and can be easily consulted in the phone's browser. On the website of the databases, clicking on the Terminologia Oberta (Open terminology) tab opens a user search surface similar to Cercaterm and Neoloteca, which allows users to download data originating from Termcat's terminology research in different file formats (PDF, XML, HTML). An advantage of making it downloadable is that the resulting data can be imported into terminology management software and used effectively during translation.

In order to describe the general characteristics of the database, it is worth considering whether semasiological or onomasiological principles have been applied in its development. Looking at the user interfaces of Cercaterm and Neoloteca, the concept-oriented approach of editing is evident from the fact that all entries are classified by subject and definitions are provided in at least one language, which makes both databases onomasiological. The general characteristics of any database show whether it is simple, traditional or complex (Tamás, 2014: 111), and in this sense both databases can be considered traditional: they are concept-oriented, they observe the principle of term autonomy, the terms are listed separately, the entries are elaborate and include definitions, and the search results are presented in separate subject fields.

The criteria used in this study adapted the criteria used for the content analysis of print and electronic dictionaries to analyse terminological databases, classifying the elements of mega-, macro-, micro- and mesostructure accordingly. If we analyse the megastructure, in the case of both databases, clicking on the question mark icon in the search interface provides links to four short Catalan-language documents: a description of the database, a list of sources of terminological data, and an explanation of abbreviations and language identifiers.

Turning to the macrostructure, the interface of the databases can be explored in Catalan, Spanish, Occitan and English, with simple and advanced search modes. As regards the content of the databases, Cercaterm provides access to the terms standardised by the Termcat Board of Supervisors through an alphabetical index in Catalan, Spanish, English, German, Italian and French, as well as to nomenclatures in Latin in the fields of botany and zoology. In Cercaterm, using the simple search mode, users can search for a term or select a language from 45 languages, including Japanese, Sardinian and Guaraní, while in Neoloteca the number of languages is more restricted (Catalan, Spanish, French, German, English and Latin). Of course, not all terms have equivalents in all of these languages. The main term must be used in a search, and it is not possible to search by language or find out which terms are in the databases in each language. As a result of the search, the main term always appears in Catalan in the list of results, with only some of the other language equivalents appearing in the entries. In both databases, the advanced search can be used to specify key words and to search for terms, the content of the definitions, the comments to the definitions, the language and 
the grammatical category of the items. There are terms and definitions belonging to 33 domains in Cercaterm, and 29 domains in Neoloteca, in a wide range of subject areas (e.g. health sciences, social sciences, sports, physics). If you search for a term using a simple search and select the language, you can click on the arrow in front of the term in the list of results to open the entry for that term. The entries contain only textual information and no images or multimedia.

As for the microstructure, in both databases the main term is Catalan. This gives the title of the datasheet, and then again the Catalan term is shown with its language identifier and grammatical category. The equivalents in other languages appear, also with their language identifier, followed by the subject heading, the Catalan definition and any comments on the definition. In regard to the mesostructure, the system of references within the database features entries that are separated from each other without internal links or links to external sources. An interesting feature of the entries is that they can be shared directly on Facebook and Twitter via the share icon, and a copiable link can be created.

The first thing to consider when looking at information on the use of the database is its usability and user-friendliness. In the TERMCAT databases the system of abbreviation is logically structured, and by clicking on the question mark icon in the search interface the list of abbreviations used and their explanations appear. The search interfaces are easy to use, user-friendly and free of superfluous, distracting elements, enabling searching to be quick and efficient. They serve language policy purposes and are well-suited to achieving these purposes, as they contribute to the dissemination of terminological data as widely as possible.

\subsection{UBTERM}

UBTERM is the terminology database of the University of Barcelona (Universitat de Barcelona, https://www.ub.edu/), a collection of all the dictionaries and glossaries compiled by the university community in collaboration with the Language Services (Serveis Lingüistics, http://www.ub.edu/sl/ca/). The database brings together the terms used in university-related activities (teaching, research). The mission of the University's Language Services is to promote education, training and research in Catalan by language teaching, supporting multilingual education, proofreading materials and publications. According to the website, the main aim of creating UBTERM database has been to promote the use of Catalan, especially for university teachers, students, translators and editors of technical and scientific texts, and teachers of specialised languages. In terms of the technical parameters, the database can be consulted through the user interface of the website, it is available to the general public without previous registration. The website does not provide any information about the software used for the database creation, or about the data being downloadable or not. 
As for the structure of the database, the user interface is simple, similar to online dictionaries'. The primary language is Catalan, the Catalan main term has a central position in each entry, accompanied by other relevant information and equivalents in other languages (Spanish, English, French, German and Italian). The terms are classified alphabetically within a total of 45 technical and scientific subjects (e.g. anatomy, biochemistry, ecology, statistics, physics), but it is also possible to perform searches in the content of each dictionary. The central element of the entry is the main term in Catalan, followed by its synonyms, equivalents in other languages, the grammatical category, the definition and other notes. There are several search methods available: it is possible to type the exact term in the search box or to use the alphabetical index, but selecting the subject field or the specific dictionary from the drop-down menu may lead to more precise results. Sometimes visual information and diagrams are also displayed within the entries. In summary, UBTERM database is quick to use, easy to search with a user-friendly interface. It can be considered as a simple database and it is more like an online dictionary: at the structure level, the database does not follow the principles of term autonomy or concept-orientation, as not all concepts have a definition.

\subsection{UPCTerm, Terminología Técnica Multilingüe}

UPCTERM is a multilingual (Catalan, Spanish, English, French and Spanish) terminology database which includes technical and technological subject fields. It has been compiled by the Linguistic and Technological Services of the Polytechnic University of Catalonia (Servicios de Lengua y Tecnología de la Universidad Politécnica de Cataluna). It has been created by the different departments of the university, with the aim of summarising the results of the terminological work carried out by the Services in the past twenty years, and providing effective assistance for authors and translators of the documents produced by the university's scientific community. The entries are regularly updated and enlarged with the new publications of the Services, taking into account the users' comments.

The terms are structured in alphabetical order, but it is possible to perform searches by subject field as well, which results in a list of all terms of the selected subject field in alphabetical order. The database contains more than 100,000 terms in 30 subject fields (e.g. mathematics, statistics, architecture, optics, mechanical engineering, electronics, information technology, telecommunications, geology, textiles, economics, chemistry), but the number of entries is not available on the website. The largest part the terminological data comes from the publications of the Services and from the terms extracted via technical translation projects, but no source data are available for the individual entries.

The Catalan main term has a central position in each entry, showing its language identifier and the subject field, followed by equivalents in other languages (Spanish, 
English, French, German and Italian), also with language identifiers. Grammatical information (indication of grammatical gender) is provided only for the Catalan term, and sometimes there is a definition in Catalan, notes to the definition or Catalan synonyms. Two search methods are available for the user: alphabetical or interactive. In the case of an alphabetical search, it is possible to select first the language of the search, the subject field, then select the initial letter of the term from the alphabetical list. The disadvantage of this search method is that users have to scroll down the list until they find the search term, which is a time-consuming process. As for the interactive search method, the user can type the term in the search field, which results in a list with all terms that contain the search element. It is possible to specify the search: by exact term (exactament), by terms containing the search element (termes que contenen), by the first element of the term (termes que comencen por), by the last element of the term (termes que acaben en). The user can also perform a search within the definitions. In summary, the analysed database is very similar to UBTERM both in terms of its user interface and its structure. UPCTERM can be considered as a simple database and it is more like an online dictionary in its appearance.

\subsection{Catalan terminology for IATE}

IATE (Interactive Terminology for Europe, https://iate.europa.eu/home) is the EU's interinstitutional terminology database containing terms, abbreviations, acronyms and phraseology in the official languages of the European Union. It was compiled in 1999 with the aim of creating a web-based infrastructure to collect, disseminate and manage EU-specific terminology. As of November 2018, the new, more modern version of IATE, which is based on state-of-the-art technology, is available for the translators and terminologists of the different EU institutions, and some of the data is made public. The database serves as a primary reference for the translation of EU documents, it has a user interface prepared by the EU, and some of the data can be downloaded and integrated into translation tools. It currently contains more than 8 million terms in the 24 official languages, and in addition, in certain subject fields, it includes terms in Latin as well. The database plays a crucial role in establishing equivalence between multilingual documents, which are indispensable for the functioning of the European Union. The structure of the terminological entries is hierarchical, reflecting an onomasiological approach, in which concept-related information is presented at three levels: 1) at language-independent level, 2) at linguistic level, and 3) at term level. Language-independent level is the level of the concept with the subject field, the source of the concept, the country or culture to which the concept is related. Linguistic level forms an intermediate level between the concept and the term, to which additional information related to the concept, such as bibliography, source and images, are added. Term level contains terms in different languages accompanied by grammatical data, notes and the reliability code (Lesznyák, 2010). Among the search criteria, the following 


\section{Eszter Sermann}

are mandatory: term, source language, target language(s). In addition to the compulsory criteria, users can find other optional ones: subject fields represented by codes, therefore it is possible to perform searches within a single subject field. At the end, users can also select the search type: term, abbreviation, etc. The new user interface of the database is easy to use and the data are regularly updated.

Catalan is not an official language of the European Union, as it is not an official language in the whole territory of Spain. Several initiatives have been taken to promote its status as an official language, since the Catalan-speaking community could be disadvantaged if EU terminology is not elaborated in Catalan. As the result of a collaboration between the Terminology Coordination Unit (TermCoord) of the European Parliament with TERMCAT and the Open University of Catalonia (Universitat Oberta de Catalunya, https://www.uoc.edu/portal/en/index.html), in 2019 the IATE Terminology in Catalan (Terminologia de IATE en català, https://www.termcat.cat/ca/diccionaris-en-linia/264) has been created with terminological principles and working methods, in the form of an online database. The aim of the database project was to elaborate the terminological data available in the IATE database in the 24 official languages of the European Union in Catalan as well, and to make them widely accessible. The database cannot be considered as prescriptive, but rather a tool to make the terminological data available to translators, terminologists, professionals and the general public, and to standardise and disseminate EU terminology in Catalan.

The database contains 16.417 entries, the interface of the entries displays the following data: 1) one or more term(s) in Catalan, grammatical category, the source of the data in each entry; 2) one or more translation equivalent(s) in English, Spanish and/or French from the IATE database, the reliability code, and the source of the data; 3) the IATE concept identifier, which is identical for the English, Spanish and French terms in the database; 4) the definition from one of the TERMCAT sources; 5) the subject field. The subject fields are various, according to the EU domains, with most entries in the fields of law, economics and health care. The entries are sorted by subject field.

The details of the methodological background for the database creation can be found on the Termcat website (https://www.termcat.cat/ca/diccionaris-enlinia/264/presentacio) and in the relevant literature (Nin Aranda, 2016; Vázquez Oliver - Ubide, 2018; Vázquez - Oliver - Casademont, 2019). Terminological dictionaries, handbooks, specialised linguistic publications, encyclopaedias, and parallel corpora have been used as sources, from which English and Spanish terms, already existing in the IATE database, were extracted automatically and registered together with Catalan terms.

During the compilation of the database, it was not possible to create all entries in Catalan, therefore the most reliable entries (entries with reliability codes 3 and 4 ) were selected and elaborated. The assignment of Catalan terms to the concepts was carried 
out in 2 steps: 1) automatic search in the corpus and extraction of Catalan terms corresponding to English terms; 2) validation of the resulting data. After validation, the Catalan terminology data were included in IATE, but only for internal use, in the initial stage data were not available to the general public. As a result of this project, Terminologia de IATE en català was published in 2019 on the TERMCAT website as an online dictionary. Currently, the collection can be consulted on the TERMCAT website and downloaded in TBX format.

\section{Conclusion}

Terminological databases are reliable and useful tools for translators, because they contain not only the basic grammatical information related to the terms, but also facilitate the conceptual analysis necessary for the translation of the terms. The creation and widespread availability of terminology databases contributes to standardizing terminology in various fields and improving the quality of professional documents and their translations. However, terminological databases not only have a direct practical benefit. High quality databases that are compiled according to terminological principles also serve language policy purposes and fulfil terminological policy tasks. In this paper five Catalan terminological databases have been analysed according to an experimental set of criteria used for the classification and evaluation of online databases. The Catalan identity has several components, one of which is language; the Catalan government and several univiersities of Catalonia have paid close attention to the regulation of the official levels of language use, prioritizing the development of terminology because it had suffered decades of neglect over the last century. The databases presented here are the result of a conscious effort by the professionals responsible for terminology and the database as well as the associated workflow, can serve as a good practice for other language communities.

\section{Works cited}

Berta, Tibor (2018). Nyelv és identitás: a katalán esete. Szépirodalmi Figyeló, 2018(1). 45-54. Brekke, Magnar (2001). LSP Lexicography and Terminography: A Complementary View. In: Mayer, Felix (ed.). Language for Special Purposes. Perspectives for the New Millenium. $V$ ol. 1. Linguistics and Cognitive Aspects, Knowledge Representation and Computational Linguistics, Terminology, Lexicography and Didactics. Tübingen: Gunter Narr. 179-187.

Cabré Castellví, María Teresa (1999). Terminology: Theory, Methods and Applications. Amsterdam-Philadelphia: John Benjamins.

Cabré Castellví, María Teresa (1996). Terminology Today. In: Somers, Harold (ed.). Terminology, LSP and Translation. Amsterdam-Philadelphia: John Benjamins. 15-34. 


\section{Eszter Sermann}

Déri, Balázs - Faluba, Kálmán (2018). Fejezetek a katalán kultúra történetéből. Szépirodalmi Figyeló, 2018(1). 26-44.

Fischer, Márta (2015). A fordító mint terminológus - A fordítás folyamatában. In: Bocz, Zsuzsanna (ed.). Porta Lingua - A XXI. századi szakmai, szaknyelvi kommunikáció kibivásai: tanári és tanulói kompetenciák. Budapest: SZOKOE. 93-107.

Fóris, Ágota (2002). Szótár és oktatás. Pécs: Iskolakultúra.

Fóris, Ágota - Bölcskei, Andrea (2019). Ajánlások a magyar terminológiastratégiához. In: Fóris, Ágota - Bölcskei, Andrea (eds.). Terminológiastratégiai kibivások magyar nyelvterületen. Budapest: OFFI - L'Harmattan. 140-164. Access date: July, 7th, 2021. Available at: https://www.offi.hu/offi-akademia/kiadvanyok/terminologiastrategiaikihivasok-a-magyar-nyelvteruleten.

Fóris, Ágota - Rihmer, Zoltán (2007). A szótárak minősítési kritériumairól. Fordítástudomány IX(1). 109-113.

Gaál, Péter (2012). Szempontrendszer online szótárak minősítéséhez. Magyar Terminológia, 5. 2012(2). 225-250.

Lénárt, András (2018). Katalónia a 20. században. RUBICON, 28. 2018(11). 54-63.

Nemes, Krisztina (2015). Függetlenség - állam - nyelv: Katalónia különös esete. Létünk, 2015(2). 117-128.

Németh, Tibor (2018). Regionális autonómia és nyelvpolitika Katalóniában. Új Pedagógiai S zemle, 2018(5-6). 116-122.

Nin Aranda, Anna (2016). Catalan terminology for LATE. Luxembourg: European Parliament. Terminology Coordination. Access date: July, 15th 2021 . Available at: https://termcoord.eu/2016/03/termcoord-and-termcat-in-close-cooperation-toenrich-iate-content/.

Papp, Eszter (2019). A terminológiastratégia kérdései Európában. In: Fóris, Ágota Bölcskei, Andrea (eds.). Terminológiastratégiai kibivások magyar nyelvterïleten. Budapest, OFFI - L'Harmattan. 94-104.

Pujol Berché, Mercè (2013). Política lingüística: lengua cultura e identidad, el ejemplo de Cataluña. Amnis. Revue d'études des sociétes et cultures contemporanies Europe-Amérique. 2013(12). Access date: July, 15 ${ }^{\text {th }}$, 2021. Available at: https://journals.openedition.org/amnis/2061.

UNESCO (2019) (Hungarian translation): Terminológiapolitikai irányelvek. A terminológiapolitika kialakítása és megvalósítása különböző nyelvközösségekben (original publication by: Infoterm, translated by Somogyi, Zoltán). In: Fóris, Ágota Bölcskei, Andrea (ed.). Terminológiastratégiai kibivások a magyar nyelvterületen. Budapest, OFFI - L'Harmattan. 167-218. Access date: July, 15 ${ }^{\text {th }}$, 2021. Available at: https://www.offi.hu/offi-akademia/kiadvanyok/terminologiastrategiai-kihivasok-amagyar-nyelvteruleten. 
Sermann, Eszter (2021). A dokumentáció terminushoz kapcsolódó fogalmak a Cercaterm katalán terminológiai adatbázisban. In: Fóris, Ágota - Bölcskei, Andrea (eds.). Tartalomfejlesztés és a dokumentáció. Nyelvészeti kutatások. Budapest: KRE L'Harmattan. 247-262.

Sermann, Eszter (2020). A Neoloteca terminológiai adatbázis mint a nyelvi identitás kifejezésének eszköze. In: Bakti, Mária - Újvári, Edit (eds.). Nyelv és identitás. Szeged: Juhász Gyula Felsőoktatási Kiadó. 49-60.

Sermann, Eszter - Tamás, Dóra (2013). Elektronikus szótár vagy terminológiai adatbázis? In: Tóth, Szergej (ed.). Társadalmi változások - nyelvi változások. Alkalmazott nyelvészeti kutatások a Kárpát-medencében. A XXII. MANYE Kongresszus elöadásai. Szeged, 2012. április 12-14. (A MANYE Kongresszusok elöadásai 9.). Budapest - Szeged: MANYE - Szegedi Egyetemi Kiadó Juhász Gyula Felsőoktatási Kiadó. 450-454.

Sermann, Eszter - Tamás, Dóra (2010). Hogyan definiálhatjuk a fordítói adatbázist? Egy olasz és egy spanyol fordítói terminológiai adatbázis vizsgálata. In: Károly, Krisztina - Fóris, Ágota (eds.). Nyelvek találkozása a fordításban. Doktori kutatások Klaudy Kinga tiszteletére. Budapest, ELTE Eötvös Kiadó: 101-116.

Szente-Varga, Mónika (2012). Katalán nyelvpolitika. Mediterrán világ, 21. 53-63.

Tamás, Dóra Mária (2015). A fordító mint terminológus. In: Horváth Ildikó (ed.). A modern forditó és tolmács. Budapest: ELTE Eötvös Kiadó. 47-66.

Tamás, Dóra Mária (2014). A gazdasági szövegek forditásának terminológiai kérdéseiröl. Fordítástudományi értekerések. I. Budapest: ELTE BTK.

Tamás, Dóra Mária - Sermann, Eszter (2020). Evaluation System for Online Terminology Databases. Terminologija, 26. 24-46.

Tamás, Dóra Mária - Sermann, Eszter (2019). Elemzési szempontrendszer terminológiai adatbázisokhoz. Fordítástudomány, 21(2). 46-62.

Vázquez, Mercè - Oliver, Antoni - Casademont, Elisabeth (2019). Using open data to create the Catalan IATE e-dictionary. Terminology: International Journal of Theoretical and Applied Issues in Special Communication, 25(2). 175-197.

Vázquez, Mercè - Oliver, Antoni - Ubide, Georgina (2018). La terminología jurídica del IATE en català. Revista de Llengua i Dret, 69. 139-153. Access date: July, 15 th 2021 . Available at: http://revistes.eapc.gencat.cat/index.php/rld/article/view/10.2436-rld.i69.2018.3010 /n69-vazquez-oliver-ubide-ca.pdf.

\section{Sources}

Catalan terminology for IATE. Access date: July, 15 $5^{\text {th }}$, 2021. Available at: https://www.termcat.cat/ca/diccionaris-en-linia/264. 


\section{Eszter Sermann}

Cercaterm. Access date: July, 15 ${ }^{\text {th }}$ 2021. Available at: https://www.termcat.cat/ca/cercaterm.

IATE. Access date: July, 15th, 2021. Available at: https://iate.europa.eu/home.

Neoloteca. Access date: July, 15 ${ }^{\text {th }}, 2021$. Available at: https://www.termcat.cat/ca/neoloteca.

Polytechnic University of Catalonia. Access date: July, 15th 2021 . Available at: https://www.upc.edu/en.

UBTERM. Access date: July, 15 th 2021 . Available at: https://www.ub.edu/ubterm/.

University of Barcelona. Access date: July, 15 th 2021 . Available at:

https://www.ub.edu/web/portal/en/.

UPCTERM. Access date: July, 15 th 2021 . Available at: https://www.upc.edu/slt/upcterm/. TERMCAT. Access date: July, 15 ${ }^{\text {th }}$, 2021. Available at: https://www.termcat.cat/ca. 